\title{
Teologická reflexe charity - obor pro „pěstování orchidejí" nebo srdce theologie
}

\author{
Markus Lehner
}

Deus Caritas est - Bůh je caritas. Tak nazval papež Benedikt XVI. svou první encykliku, která vyšla v roce 2005. A hned na začátku bere zřetel na biblické poselství citátem z Janova prvního dopisu: „Bůh je láska, a kdo zůstává v lásce, zůstává v Bohu, a Bůh zůstává v něm (1. Jan 4,16)." Tato slova prvního listu svatého apoštola Jana vyjadřují obzvláště zřetelně jádro křest'anské víry, tedy křest’anský obraz Boha, a také z toho vyplývající obraz člověka i jeho životní cesty (DCE 1).

Jestliže se tedy Bůh křest́anů jmenuje caritas, pak se tím samozřejmě rozumí, že caritas je srdcem „řeči o Bohu, " v řeckém překladu „theologie“. Že na nějaké katolické theologické fakultě existuje Ústav pro vědy o charitě (něm. Caritaswissenschaft), by toho mělo asi být logickým důsledkem! Potud teorie. Jak to ale v prostoru německojazyčné teologie vypadá prakticky?

V Německu existuje „Pracovní odbor vědy o Charitě a o křest'anské sociální práci“ na Teologické fakultě Univerzity ve Freiburgu. Dřive zde byl v roce 1925 založený Institut pro vědu o Charitě, jehož dějiny jsou úzce spojeny s Německým svazem Charity, založeným ve Freiburgu v roce 1897. S katedrou křest'anské sociální nauky a vědy o Charitě (něm. Lehrstuhl für christliche Soziallehre und Caritaswissenschaft) Ústavu pro Katolickou teologii na Univerzitě v Pasově existuje další instituce, která se zabývá teologickou reflexí charity. V Rakousku je na Katolické teologické univerzitě v Linci jediná Teologická fakulta, která disponuje Ústavem pro vědu o Charitě. Zatímco se ve Freiburgu a v Pasově jedná o plnohodnotné teologické katedry, je $\mathrm{v}$ Linci věda o Charitě pouze přičleněným ústavem, který je podřízen vedení ředitele.

Jak vlastně došlo $\mathrm{k}$ tomu, že se v Linci zrodila věda o Charitě? Nebyly to žádné průlomové poznatky dogmatiky nebo biblické teologie, ale podněty z praxe charitní práce. V prvních letech po 2. světové válce a ještě v 50tých letech byla nouze lidí tak bezprostřední výzvou, že v popředí charitní práce stála zcela pragmatická organizace pomoci: pátrání po zmizelých, dodávání potravin potřebným, poskytování zdravotního zotavení dětem atd. Teprve když se postupně dostavoval poválečný hospodářský zázrak a nastalo cosi jako normální stav, otevřel se prostor pro základní otázky Charity: Jaké jsou vlastně kořeny našeho jednání? Jaké místo má Charita v církvi?

Teologie měla v této době bezprostředně po Druhém vatikánském koncilu jiné priority: reforma liturgie, nové strukturování diecézí a farností z hlediska nároků teologie Božího lidu - to vše bylo v rámci synodů 70tých let mocně diskutováno. Teologické ukotvení charitní práce se vůči těmto naléhavým tématům jevilo jako periferní problém. Adekvátně k tomu bylo tedy pro osoby odpovídající za řízení Charity těžké najít teology, kteří by byli ochotni se zabývat a vyrovnávat s charitními tématy. Nakonec byla Charita úspěšná až u pastorálního teologa tehdejší Filosoficko-teologické vysoké školy v Linci Wilhelma Zaunera. Nereferoval jen o základních teologických otázkách na konferenci ředitelů rakouské Charity, ale pocházejí od něj také první příspěvky k teologii Charity do časopisu Německého svazu Charity. Tak byla Teologická fakulta v Linci již od 60. a 70. let pro Charitu cílovou adresou v případech, kdy šlo o teologické otázky. 
Trvalé institucionální naplnění však mělo toto angažmá dostat až v 90. letech. Iniciativa pro to vyšla opět z Charity. Na podzim roku 1989 se vedení Diecézní charity v Linci obrátilo na Ústav pastorální teologie s dotazem, zda by bylo možné vyvinout nabídku dalšího vzdělávání pro odpovědné osoby v Charitě. Stále výrazněji se diferencovala odbornost vedení Charity, jednotná církevní socializace a společné základní porozumění křest́anským kořenům charitní práce mohly být předpokládány stále méně. Propojení Charity a pastorace bylo postupně pocit́ováno jako problematické. Výsledkem této iniciativy byl po mnoha intenzivních diskuzích v roce 1991 Vysokoškolský kurz Charita (něm. Hochschullehrgang Caritas). Zjevně tím byl zasažen nerv, poněvadž o toto studium byl velký zájem. Účastníci přicházeli nejen z mnoha rakouských spolkových zemí, ale též ze zemí sousedních.

$\mathrm{V}$ roce 1999 pak došlo $\mathrm{k}$ trvalé institucionalizaci tématu věda o charitě zřízením Ústavu pro vědu o Charitě s vlastním biskupským statutem, který byl přičleněn ke Katolické teologické vysoké škole v Linci. Z hlediska vedení nebyla věda o Charitě dosti významná pro to, aby pro ni byla zřízena vlastní katedra - nebyl to žádný klíčový obor teologie, nýbrž obor pro pěstování orchidejí. Tato pozice je symptomatická pro postavení teologické reflexe charity v teologii. V základu sedí na dvou židlích. Jak z hlediska teologické fakulty, tak z hlediska praxe církevní sociální práce je v nejlepším případě okrasnou orchidejí.

Z hlediska teologických fakult to vyplývá zcela pragmaticky z jejich vzdělávacího cíle. V první řadě jde o vzdělávání pracovníků pro pastoraci a výuku náboženství. Oběma skupinám určitě neuškodí, jestliže uslyší něco o Charitě, která se přece počítá mezi základní způsoby realizace církve. Nicméně v porovnání s jinými tématy se určitě nejedná o centrální obsah vzdělávání, protože i profesní činnost v pastoraci a výuce náboženství má v praxi jiná těžiště.

Z druhé stany Charita jako profesionální organizace skutečně nemá teologické fakulty ve svém úhlu při získávání nových spolupracovníků. „Nemám nic proti teologům, pokud jsou připraveni doplnit si vzdělání," řekl jeden rakouský ředitel Charity v rozhovoru o pracovních možnostech absolventů teologických fakult.

Zahradní centra učinila z orchidejí díky průmyslovým metodám produkce masové zboží. Původně byly považovány za cosi ojedinělého a drahého. Podobně je také teologická reflexe Charity jakýsi ojedinělý fenomén, připomínající cosi drahého: skutečnost, že láska Boha k lidem se stává skutečností skrze naše jednání vůči lidem chudým, potřebným, s omezenými možnostmi, nemocným, s postižením, potřebujícím péči. Angažmá Charity pro tyto lidi je svědectvím o Bohu, které je pro mnohé současníky bezprostředně pochopitelné a je pro ně navíc srozumitelnější než teologické traktáty. Charita mluví ve svém každodenním jednání o Bohu dialektem, který se dotýká srdce mnoha lidí, motivuje je k angažování v solidaritě se slabšími naší společnosti. Ještě jednou cituji papeže Benedikta XVI. a jeho encykliku Deus Caritas est: „Ten, kdo uplatňuje lásku (caritas) ve jménu církve, (...) ví, že láska ve své čistotě a nezištnosti je tím nejlepším svědectvím vydávaným Bohu, v něhož věříme a jenž nás pohnul k tomu, abychom milovali. Křest́an ví, kdy je vhodná doba o Bohu mluvit a kdy je zase správné o Něm mlčet a nechat promlouvat pouze lásku. Křest́an ví, že Bůh je láska (srov. 1 Jan 4, 8) a že se zpřítomňuje právě v okamžicích, v nichž se nekoná nic jiného než láska (DCE 31.c)."

K čemu je pak ještě potřebná věda o Charitě jako teologická disciplína? Jsem přesvědčen, že ji potřebujeme, a to jako tlumočníka. Musí být tlumočníkem mezi zkušenostmi Boha charitní praxe a systematickou řečí o Bohu teologie. Jednak má úkol zprostředkovat teologům, že jejich řeč o Bohu musí být uzemněna ve zkušenostech lásky Boha k lidem, které jsou znatelné v často namáhavé praxi charitní práce, poněvadž jinak se řeč o Bohu stává elitářskou a povýšeneckou. Na druhé straně je jejím úkolem poskytovat praktikům v Charitě interpretační pomoc - pomoci jim k tomu, aby svou každodenní práci viděli očima víry, rozuměli jí jako malým krokům na cestě do Božího království.

Pro zajištění této tlumočnické služby snad ani není zapotřebí, aby byla teologická reflexe Charity téměř plošně uskutečňována na všech teologických fakultách jako pevně zakotve- 
ná teologická disciplína. Důležitou roli zde mají ti teologové, kteří jsou zaměstnáni v Charitě a jsou tak blíže ke každodenní charitní praxi. Ti ale nicméně potřebují inspiraci a doprovázení, potřebují teologicky kompetentní posilňování pro svou tlumočnickou službu mezi teologií a výzvami současné sociální práce.

V obývacích pokojích Rakouska se zásluhou průmyslové produkce mezitím staly orchideje standardním módním doplňkem. Na teologických fakultách zůstane věda o Charitě zřejmě i nadále jakousi raritou, nicméně snad právě v tom spočívá její potenciál. Podaří-li se zprostředkovat právě $v$ takovém postavení pestrost a záři Boží lásky, může se věda o Charitě projevit i jako srdce řeči o Bohu.

Tento text vznikl na základě přednášky prof. Markuse Lehnera prì príležitosti 10. výročí (1999-2009) založení Institutu pro vědu o charitě prì Katolické teologické univerzitě v Linci. 